\title{
Rasch calibration and optimal categorization of the Rosenberg Self-Esteem Scale with Korean elite young soccer players
}

\author{
Myungjin Jung ${ }^{1}$, Heontae Kim $^{1}$, \& Minsoo Kang ${ }^{1}$ \\ ${ }^{1}$ University of Mississippi
}

\begin{abstract}
[Purpose] The purpose of this study was to determine item goodness-of-fit and the optimal categorization of an instrument measuring Korean elite young soccer player's self-esteem using a two-facets Rasch model (item parameters and person parameters). [Methods] 10-item Rosenberg Self-Esteem Scale (RSES) with five response categories was administered to 366 elite young soccer players from the Korea football association. The Rasch analysis was conducted by WINSTEPS 3.65. [Results] First, the model fit the data well. Second, 5-category rating scale did function well. Third, a item-person map illustrated the distribution of RSES items and person's level of self-esteem. Fourth, the separation reliability of the items and person was shown to be an acceptable degree of confidence, respectively. Lastly, there was statistically significant difference in self-esteem between starting players and bench players, which supported the known-difference evidence of validity. [Conclusion] These findings provided additional support for the suitability of the RSES in assessing self-esteem of Korean elite young soccer players.
\end{abstract}

Key words: category function, elite soccer players, Rasch model, self-esteem

\section{서 론}

자아존중감은 개인의 주관적 경험, 삶의 만족, 그리고 정신건강과 밀접하게 관련된 중요한 심리적 개념으로, Rosenberg(1965)는 자아존중감을 '자기 자신이 소중하 고 가치 있는 존재이며 자신이 어떤 일을 성공적으로 수 행할 수 있다고 여기는 강한 믿음의 상태'라고 정의하였 다. 인간의 성격 발달에 영향을 미치는 자아존중감은 교 육(Flouri, 2006), 심리(Chao et al., 2017), 보건 (Park et al., 2019), 체육(Jung et al., 2016) 등 수많 은 분야에서 연구가 진행되었다.

논문 투고일 : 2020. 08. 20.

논문 수정일 : 2020. 10. 19.

게재 확정일 : 2020. 12. 09

* 교신저자 : 정명진(mjung4@go.olemiss.edu).
인생의 전 시기를 통해 형성되고 발달하는 자아존중감 은 청소년기에 획득해야 할 중요한 발달 과업으로써, 청 소년기에는 신체 및 생리적 변화, 인지적 발달, 학업 스트 레스 등 복합적인 요인으로 개인의 정체성이 역동적으로 변화할 가능성이 크다(Ohannessian et al., 1995). 즉, 청소년은 다양한 변화에 빠르게 적응해야 한다는 점에서 어려움을 겪게 되며, 이때 올바른 자아존중감을 형성하지 못하면 성인이 되어서도 심리적 부적응을 보일 수 있다 (Deering \& Schill, 2008). 한편, 학생과 선수의 역할을 동시에 수행해야 하는 엘리트 청소년 축구선수는 코치 및 팀원들과의 관계, 성적에 따른 부담감, 고된 훈련 등 많은 압박감을 느낀다(Goldberg, 1991). 이와 같은 상황에서 엘리트 청소년 축구선수가 발달 과정상 겪게 되는 스트레 스를 이겨내고 경기력 향상에 도움을 주는 심리적 요인이 바로 자아존중감이다(Chung et al., 2009). 자아존중감이 
높은 엘리트 청소년 축구선수는 기본적으로 자신에 대해 긍정적인 평가를 내리며 자신이 하는 일에 강한 자부심을 느낀다. 그리고 어떠한 상황 속에서도 자신감을 가지고 도 전하며, 주변 환경이나 사회관계에서도 안정감과 소속감 을 느껴 좋은 대인관계를 유지한다. 반면, 자아존중감이 낮은 엘리트 청소년 축구선수는 실패에 대한 두려움으로 새로운 과제에 도전하기를 꺼려하고 자기 자신에 대해 부 정적인 평가를 하며 자신의 능력과 미래에 대해서도 비관 적인 생각을 가진다. 또한, 우울, 스트레스, 사회 부적응 등의 여러 정신 질환을 겪을 가능성이 높다(Kim et al., 2014).

국내외 여러 선행연구에서도 자아존중감의 역할을 강 조하며 자아존중감을 정확하게 측정하기 위한 노력이 이 루어져 왔다(Choi \& Cho, 2013; Classen et al., 2007; Mannarini, 2010). 자아존중감을 측정하는 도구 중 가 장 보편적으로 사용되고 있는 것이 바로 Rosenberg의 Self-Esteem Scale(RSES)이다. RSES는 다양한 나라 의 언어로 번안되어 사용되어왔고, 비교적 안정적인 타당 도와 신뢰도를 보였다(Roth et al., 2008; Schmitt \& Allik, 2005).

하지만 고전검사이론(classical test theory)에 근거 하여 RSES를 분석한 연구는 측정학적 관점에서 몇 가지 문제점을 보였다. 첫째, 평정척도(rating scale)에서 사 용되는 반응범주의 동간성 부재로 수집된 자료로부터 총 점을 계산하여 피험자의 수준을 파악하는 것은 부적합하 다(Kang et al., 2007). 둘째, 문항의 고유한 특성이 피 험자 집단의 수준에 따라 변하며, 피험자의 수준 또한 문 항의 특성에 따라 다르게 나타난다(Petrillo et al., 2015). 셋째, 측정도구의 반응범주 수를 결정하는데 있 어 응답자의 특성을 고려하기보다 연구자의 주관적 경험 과 판단에 의존한다(Zhu \& Kang, 1998).

이러한 한계를 해결하기 위해 학자들은 문항반응이론 (item response theory) 중의 하나인 Rasch 평정척도 모형의 사용을 제안하였다(Rasch, 1960; Wright \& Linacre, 1989). Rasch 모형의 기본 논리는 피험자의 능 력(personal ability)과 문항난이도(item difficulty)의 차이에 의해 피험자가 특정 문항에 응답할 확률을 구하여 그 확률을 로지트(logit) 점수로 변환시키는 것이다. 변 환된 로지트는 동간척도의 성격을 갖게 되며 피험자 능력
과 문항난이도 추정치를 단일선형척도 상에서 비교한다. 또한, 불변성 개념에 기초하여 문항의 특성이 피험자 집 단의 특성에 따라 변하지 않으며, 피험자의 능력 또한 어 떠한 검사를 시행하든 고유한 수준을 유지한다. 반응범주 수의 적절성은 각 범주에 대한 평균 측정치, 임계치, 그리 고 적합도 통계치 등을 통해 평가된다(Kang, 2001).

한편, 체육 분야에서도 Rasch 모형을 활용한 연구가 이루어졌다. Anshel et al.(2009)는 Rasch 모형을 활용 하여 경쟁 스포츠 상황에서 완벽주의를 측정하는 도구 (Sport Perfectionism Scale; SPS)의 요인구조와 타당 도를 분석하였고, 그 결과 단일차원의 SPS 척도를 개발 하였다. 여성을 대상으로 운동방해 측정도구(Women's Exercise Perseverance and Barriers)를 개발한 Zhu et al. (2001)은 기존의 5점 척도보다 3점 척도가 더 적합한 범주임을 확인하였고, 이후 장애아동을 대상으로 연구한 Kang et al. (2007)은 문항난이도 분석에서 시간 부족과 신체적 고통이 장애아동들의 운동참여에 가장 큰 방해요 인이라는 것을 밝혔다.

국내 체육 분야에서 엘리트 청소년 축구선수를 대상으 로 빈번하게 사용되고 있는 RSES는 주로 다른 심리적 변 인과의 관계를 살펴보았을 뿐(Kang et al., 2015; Jung et al., 2016), 측정도구 자체의 기능에 관해서는 아무런 의문을 제기하지 않았다. 또한, 대부분의 연구들은 앞서 언급한 엘리트 청소년 축구선수들의 상황 및 문화적 특수 성에 대한 고려 없이 일반인을 측정하기 위해 개발된 $\mathrm{RSES}$ 를 오래전부터 그대로 적용하여 사용해왔다. RSES 가 연구대상의 특성들에 영향을 받는다고 강조한 Goldsmith(1986)의 주장대로 개인의 가치를 결정하는 요소들에 있어 엘리트 청소년 축구선수들과 일반 학생들 간에 차이가 있을 수 있다는 가정에서 이와 같은 의문을 제기해 보았다. 그동안 측정학적 관점에서 RSES의 신뢰 도 및 타당도와 관련된 근거를 제시하는 연구는 많았으나 (Lee et al., 2009) 엘리트 청소년 축구선수만을 대상으 로 Rasch 모형을 적용한 연구는 거의 없었다. 축구가 우 리나라에서 가장 인기가 높은 스포츠이자 엘리트 청소년 선수의 숫자가 많은 종목인 점을 고려했을 때, 본 연구의 연구자들은 다양한 해석을 제공해주는 Rasch 모형을 활 용한 RSES의 재검증이 필요하다고 인식하였다. 따라서 본 연구에서는 문항반응이론의 Rasch 평정척도 모형을 
적용하여 엘리트 청소년 축구선수들의 자아존중감을 측정 함에 있어 RSES가 적합한 기능(문항적합도, 반응범주의 적절성, 문항난이도의 적절성 등)을 하는지 살펴보고자 한다. 본 연구를 통해 엘리트 청소년 축구선수에게 적합한 자아존중감 척도의 문항과 반응범주 수가 검증된다면, 자 아존중감 척도의 심리측정학적 질을 향상시킬 뿐만 아니 라 엘리트 청소년 축구선수들의 자아존중감을 진단하는 구체적인 방법을 제공하여 코칭관련 연구에 도움을 줄 것 으로 기대된다.

\section{연구방법}

\section{연구대상 및 연구절차}

본 연구에서는 인구 대상자의 표집을 위해 집략표본추 출법(cluster sampling)을 실시하여 대한축구협회에 등 록된 고등학교 남자 축구선수 383 명을 대상으로 설문을 하였다. 설문을 진행하기에 앞서 연구의 윤리적 문제를 해결하기 위해 IRB의 승인을 받아 진행하였으며 연구참 여자의 부모에게 동의서를 받은 후에 IRB의 연구윤리 수 준 규정에 맞춰 연구를 진행하였다. 설문조사는 2014년 5월부터 2014년 7월까지 방문조사를 통해 실시되었고, 그중 응답 내용이 편중되거나 불성실한 응답으로 연구 분 석에 적합하지 않다고 판단된 17 명의 자료를 제외한 366 명의 자료를 바탕으로 연구를 진행하였으며, 연구대상의 특성은 아래〈Table 1〉과 같다.

Table 1. Characteristic subjects

\begin{tabular}{cccc}
\hline \hline \multirow{2}{*}{ Variables } & \multirow{2}{*}{ Classification } & \multicolumn{2}{c}{ Players } \\
\cline { 3 - 4 } & & $\mathrm{N}$ & $\%$ \\
\hline \multirow{2}{*}{ Selected to } & Starting player & 160 & 43.7 \\
start or not & Bench player & 206 & 56.3 \\
\hline \multirow{2}{*}{ Age (years) } & 17 & 126 & 34.4 \\
& 18 & 122 & 33.4 \\
& 19 & 118 & 32.2 \\
\hline \hline Total & & 366 & 100 \\
\hline \hline
\end{tabular}

청소년 축구선수의 자아존중감을 측정하기 위해 Rosenberg(1965)가 개발한 자아존중감 검사지를 국내 선행연구들이 변안하여 사용한 단일요인 10 문항 도구를 사용하였다. 자아존중감 검사지는 긍정문항 5 개 (예, "내 자신에 대해 긍정적인 태도를 갖고 있다")와 부정문항 5 개(예, "나는 대체로 실패한 사람이라는 느낌을 갖는 편이 다")로 구성되며, '전혀 그렇지 않다'(1)에서 '매우 그렇 다'(5)의 5점 리커트 척도로 이루어져 있다. 전체 점수가 높을수록 자아존중감 수준이 높음을 의미하며, 부정문항 인 $3,5,8,9,10$ 번은 역입력하여 채점된다. 구체적인 문 항 내용은 아래〈Table 2 〉와 같다.

Table 2. RSES questionnaire

\begin{tabular}{cl}
\hline \hline$\#$ & \multicolumn{1}{c}{ Questions } \\
\hline 1 & $\begin{array}{l}\text { I feel that I am a person of worth, at least on an equal } \\
\text { plane with others. }\end{array}$ \\
2 & I feel that I have a number of good qualities. \\
3 & I am inclined to feel that I am a failure. (R) \\
4 & I am able to do things as well as most other people. \\
5 & I feel I do not have much to be proud of. (R) \\
6 & I take a positive attitude toward myself. \\
7 & On the whole, I am satisfied with myself. \\
8 & I wish I could have more respect for myself. (R) \\
9 & I certainly feel useless at times. (R) \\
10 & At times I think I am no good at all. (R) \\
\hline \hline
\end{tabular}

Note. $\mathrm{R}=$ reversed-scored item.

\section{자료분석}

본 연구는 모형-자료의 적합성, 반응범주 수의 타당성, 문항난이도와 피험자 능력의 적합성 등을 검증하기 위해 2 국면 Rasch 평정척도 모형을 활용하였고, 모든 분석에 서 WINSTEPS 프로그램 (version 3.65)을 사용하였다. 국면은 문항난이도와 피험자 능력의 2 국면으로 설정하여 분석하였고 모형 공식은 다음과 같이 정의하였다.

$$
\ln \left[\frac{P_{n j k}}{\left(1-P_{n j(k-1)}\right)}\right]=D_{n}-C_{j}-F_{k}
$$

\section{검사도구}


$P_{n j k}=$ 자아존중감 문항 $\mathrm{n}$ 이 피험자 $\mathrm{j}$ 로부터 $\mathrm{k}$ 의 평정 을 받을 확률

$$
\begin{aligned}
& P_{n j(k-1)}=\text { 자아존중감 문항 } \mathrm{n} \text { 이 피험자 } \mathrm{j} \text { 로부터 } \mathrm{k}-1 \text { 의 } \\
& \quad \text { 평정을 받을 확률 } \\
& D_{n}=\text { 자아존중감 문항 } \mathrm{n} \text { 의 난이도 } \\
& C_{j}=\text { 피험자 } \mathrm{j} \text { 의 자아존중감 능력 수준 } \\
& F_{k}=\text { 평정범주 } \mathrm{k}-1 \text { 에 대한 범주 } \mathrm{k} \text { 의 난이도 }
\end{aligned}
$$

Rasch 모형의 적용에 앞서 Rasch 분석의 기본 가정인 측정도구의 일차원성 가정을 검증하기 위하여 WINSTEPS 프로그램의 표준잔차 주성분 분석 (principal component analysis of standardized residuals)을 실시하였다. 일 차원성 가정은 (1) 제 1성분의 고유값(eigenvalue)이 3 미만, (2) 제 1 성분에 의해 설명되는 분산의 변량이 $10 \%$ 미만일 경우에 충족되는 것으로 간주한다(Cordier et al., 2018; Linacre, 2016).

분석 절차는 5 단계로 구성하였다. 첫째, 모형-자료의 적합성 (model-data fit) 검증을 위해 문항 내적합도 (infit statistic)와 외적합도(outfit statistic)를 사용하 였다. 내외적합도는 카이제곱과 같은 형태를 거쳐 피험자 와 문항에서 발생하는 잔차 제곱의 평균값을 이용하여 값 을 산출하며 그 범위는 0에서부터 무한 양수이다. 내외적 합도는 1 에 가까울수록 적합하며 .5에서 1.5 사이에 있으 면 내외적합도를 만족하는 것으로 간주한다(Kang et al., 2007). 적합도 지수가 .5 미만일 경우에는 반응의 다 양성이 제한적이며, 1.5 를 초과할 경우 반응의 다양성이 지나치게 크다고 할 수 있다. 두 적합도 중 하나라도 기준 범위에서 벗어날 경우, 해당 문항을 삭제하고 모든 문항 이 적합도 기준을 만족할 때까지 반복 측정한다(Wright \& Linacre, 1994).

둘째, 최적화된 반응범주 수를 측정하기 위해 Linacre (2002)가 제안한 유도지표 중 다음의 5가지 지표를 선택 하여 평가에 이용하였다. (1) 각 범주의 선택빈도가 10회 이상이어야 한다, (2) 각 범주에 속한 피험자의 평균 측 정치는 증가하되, 그 범주가 반영하는 순서에 따라 일괄 적으로 증가해야 한다, (3) 외적합도는 2.0 미만이어야 한다, (4) 범주 간 경계를 나타내는 임계치가 그 범주가 반영하는 순서에 따라 서열화 되어야 한다, (5) 5점 리커
트 척도의 경우 최소 임계치간 거리가 1.0 로지트 이상씩 증가해야 하고, 인접한 임계치간 간격은 5.0 로지트 이하 여야 한다. 위 5 가지의 기준을 충족하지 못하면 문제가 되는 범주를 인근 범주와 병합하여 재분석한다.

셋째, 로지트 점수로 변환된 피험자의 능력과 문항난 이도를 문항-피험자 지도(Item-person map) 위에 배열 하여 두 추정치의 분포를 비교하였다. 문항 로지트 점수 가 높을수록 피험자가 동의하기 어려운 문항이며, 피험자 로지트 점수가 높을수록 높은 수준의 자아존중감 능력을 지닌 피험자로 간주한다(Anshel et al., 2009).

넷째, 문항과 피험자의 분리지수(separation index) 및 분리신뢰도(separation reliability)를 측정하였다. 분리지수의 크기가 2.0 이상이면 양호한 수준이며 그 크 기가 클수록 더 나은 분리를 하는 것으로 간주한다(Bond $\&$ Fox, 2007). 즉, 문항 분리지수가 크다는 것은 측정도 구에 포함된 각 문항의 내용이 서로 중복되지 않고 다양 한 난이도 수준에서 측정되고 있음을 의미하며, 피험자 분리지수가 크다는 것은 측정도구가 피험자 개개인의 능 력 차이를 잘 보여준다고 해석할 수 있다. 문항 분리신뢰 도는 피험자에게 동일한 문항난이도를 재현시키는 정도 를 나타내며, 피험자 분리신뢰도는 문항들이 피험자의 수 준을 얼마나 일관되게 재현하는가를 의미한다. 분리신뢰 도의 범위는 0 에서부터 1 까지이며, 1 에 가까울수록 신뢰 도가 높다(Fisher, 1992).

마지막으로 주전선수의 자아존중감이 비주전 선수보 다 높은 경향을 보인다는 선행연구의 결과(Kim \& Shin, 2017; Jung, 2015)에 근거하여 청소년 축구선수의 주전 여부에 따른 자아존중감의 차이를 알아보기 위해 SPSS 25.0 을 활용하여 독립표본 t검정을 실시하였고, 이를 통 해 차이가 예상되는 집단과의 비교를 통한 타당도 (known-group difference validity)를 검증하였다. 통계 적 유의 수준은 $\alpha=.05$ 로 설정하였다.

\section{연구결과}

\section{모형-자료 적합성}

모형-자료 적합성 결과는 아래 제시된 〈Table 3〉과 같 
다. 10 개 문항의 내적합도는 . $77 \sim 1.25$ 범위를 나타냈으 며, 외적합도는 .76 1.28 분포를 보여 모형-자료 적합 도 기준을 만족하였다. 또한, 제 1 성분의 고유값이 3 미 만(2.3)이고, 제 1 성분에 의해 설명되는 분산의 변량이 $10 \%$ 미만(9.3\%)인 것으로 나타나 본 연구에서 사용한 측정도구가 일차원성 가정을 만족하는 것을 확인하였다.

Table 3. Summary of RSES items (10 fit items)

\begin{tabular}{ccccc}
\hline \hline Items & $\begin{array}{c}\text { Calibration } \\
\text { (logit) }\end{array}$ & SE (logit) & Infit MnSq & Outfit MnSq \\
\hline Item 10 & 1.04 & .08 & 1.25 & 1.28 \\
Item 5 & .36 & .08 & .86 & .87 \\
Item 7 & .31 & .08 & 1.07 & 1.02 \\
Item 2 & .07 & .08 & .81 & .84 \\
Item 8 & .02 & .08 & .91 & .71 \\
Item 4 & -.25 & .08 & 1.05 & 1.09 \\
Item 9 & -.28 & .08 & 1.11 & 1.03 \\
Item 6 & -.35 & .08 & .77 & .76 \\
Item 1 & -.45 & .08 & 1.05 & 1.06 \\
Item 3 & -.48 & .08 & 1.00 & 1.01 \\
\hline \hline
\end{tabular}

Note. $\mathrm{MnSq}=$ mean square residual.

\section{반응척도 범주기능}

자아존중감 검사지의 응답범주 수가 적절한지 알아보 기 위해 Rasch 모형을 활용하여 응답범주의 적절성을 통 계적으로 검증하였다. 5 점 리커트 척도로 구성된 자아존 중감 검사지의 반응범주 기능검사 결과, 〈Table 4〉와 〈Figure 1〉에서 볼 수 있듯이, 각 범주가 선택된 빈도는 10 회 이상이었으며 $(48 \sim 1,435)$, 각 범주를 선택한 피험 자들의 평균 로지트 점수를 나타내는 평균 능력치는 -.81, -.41, .53, 1.73, 3.15 등으로 크기에 따라 순차적 으로 배열되었다. 외적합도의 범위는 .88 1.29로 기준 값인 2.0 이내에 포함되었다. 임계치 또한 범주 순서에 따라 크기순으로 배열되었고, 임계치간 간격도 만족할 만 한 수준이었다. 즉, 5 점 척도가 적절한 것으로 나타났다.
Table 4. Summary of rating scale function

\begin{tabular}{ccccc}
\hline \hline Category & Counts used & $\begin{array}{c}\text { Average } \\
\text { measure }\end{array}$ & $\begin{array}{c}\text { Outfit } \\
\mathrm{MnSq}\end{array}$ & $\begin{array}{c}\text { Category } \\
\text { thresholds }\end{array}$ \\
\hline 1 & 48 & -.81 & 1.29 & None \\
2 & 270 & -.41 & 1.01 & -2.43 \\
3 & 877 & .53 & .88 & -1.06 \\
4 & 1435 & 1.73 & .95 & .59 \\
5 & 880 & 3.15 & 1.06 & 2.89 \\
\hline \hline
\end{tabular}

Note. $\mathrm{MnSq}=$ mean square residual.

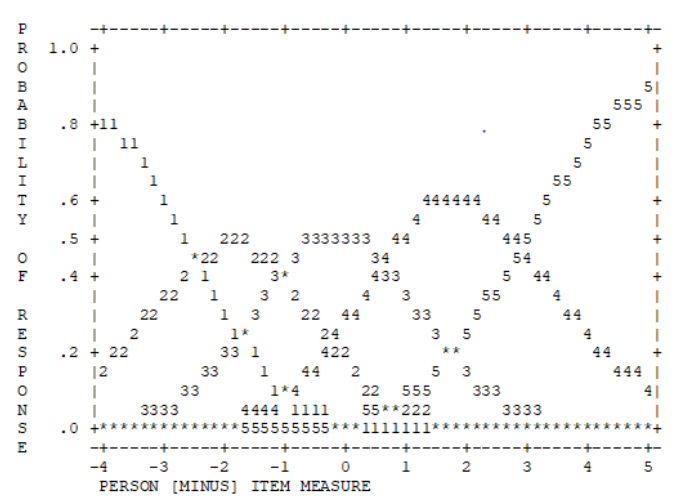

Fig. 1. Category probability curves for RSES.

\section{문항-피험자 지도(Item-person map)}

〈Figure 2〉는 자아존중감 검사지의 난이도가 엘리트 청소년 축구선수들의 수준을 적절하게 평가하고 있는지 를 살펴보기 위하여 로지트 단위로 표시된 단일선형척도 위에 문항난이도와 피험자의 능력 수준을 함께 배열한 것 이다. 좌측은 응답자들의 분포이며 우측은 엘리트 청소년 축구선수들의 능력에 따른 문항의 위치를 나타낸다. 문항 난이도의 범위는 〈Table 3〉에 나타난 바와 같이 -.48 1.04의 분포를 보이며, 로지트 점수가 높을수록 피험자가 주어진 진술에 동의하기 어렵다. 10 번 문항이 피험자가 가장 동의하기 어려운 문항으로 확인되었고 (1.04), 가장 동의하기 쉬운 문항은 3 번 문항이었다 (-.48). 피험자 능력 수준의 범위는 $-2.03 \sim 6.2$ 로 나타 났으며, 로지트 점수가 높을수록 피험자의 능력이 높다. 
문항-피험자 지도에 따르면, 중간 난이도에 해당하는 문 항은 고르게 분포하고 있으나 로지트 점수 1.0 이상에 분 포하는 높은 수준의 피험자를 변별할 수 있는 문항이 없 는 것으로 나타났다.

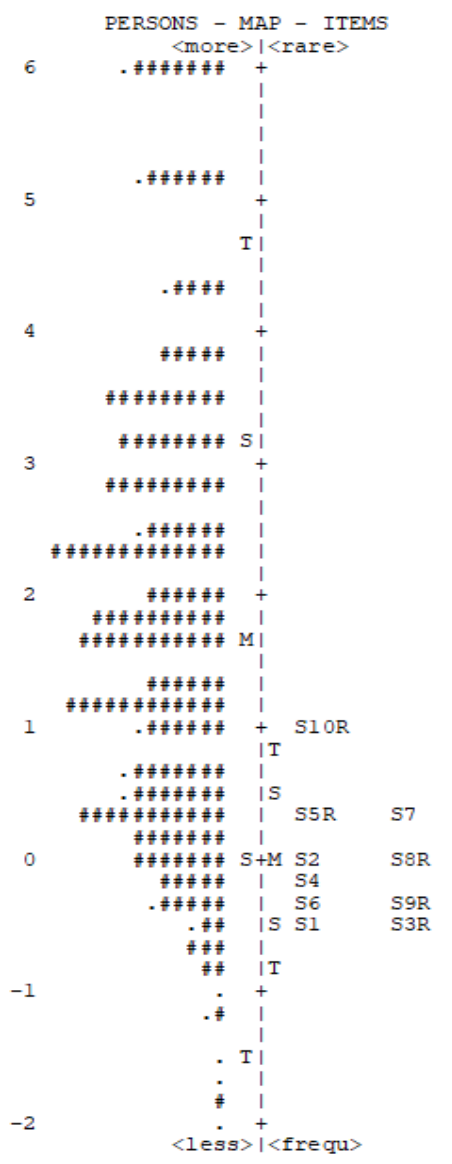

Note. Each '\#' represents 2 participants while '.' indicates a single participant.

Fig. 2. Item-person map of RSES.

\section{분리지수 및 분리신뢰도}

문항 분리지수는 5.29 로 측정도구가 각 문항의 차이를 잘 정의하고 분리하였고, 문항 분리신뢰도는 .97로 전체 피험자에 걸쳐 동일한 문항난이도를 재현하고 있는 것으 로 나타났다. 피험자 분리지수는 2.46으로 측정도구의 문항난이도가 적절하게 편성되었고, 피험자 분리신뢰도
는 .86으로 피험자의 수준을 일관되게 측정하고 있는 것 으로 나타났다.

\section{차이가 예상되는 집단 간의 비교타당도(known-group difference validity) 검증}

차이가 예상되는 집단과의 비교를 통한 타당도 검증을 위하여 독립표본 $\mathrm{t}$ 검정을 활용하여 주전여부에 따라 자 아존중감에 차이가 있는지를 살펴보았다. 〈Table 5〉를 살펴보면, 자아존중감에서 주전과 비주전 간 통계적으로 유의한 차이가 있는 것으로 나타났다. 특히, 팀에서 주전 으로 활약하고 있는 선수의 자아존중감이 더 높은 경향을 보이는 것으로 나타나 차이가 예상되는 집단 간 비교타당 도가 검증되었음을 확인하였다.

Table 5. Summary of player's level of self-esteem by role level (starting player or bench player)

\begin{tabular}{lcccc}
\hline \hline \multicolumn{5}{c}{ Person's level of self-esteem (in logits) } \\
\hline Role level & $\mathrm{N}$ & $\mathrm{M}$ & $\mathrm{SD}$ & $\mathrm{t}$ \\
\hline $\begin{array}{c}\text { Starting } \\
\text { player }\end{array}$ & 160 & 2.03 & 1.72 & \\
$\begin{array}{l}\text { Bench player } \\
\text { *p<.05 }\end{array}$ & 206 & 1.59 & 1.82 & \\
\hline \hline & & & & \\
& & & & \\
& & 논 의
\end{tabular}

본 연구는 Rasch 평정척도 모형을 적용하여 Rosenberg의 자아존중감 검사지가 엘리트 청소년 축구 선수에게 적합하게 사용되고 있는지를 검증하기 위해 모 형-자료 적합도, 반응범주의 타당성, 문항난이도와 피험 자 능력 적합성 등을 분석하였다. 엘리트 청소년 축구선 수들을 대상으로 RSES의 문항 적합도를 알아보기 위해 모형-자료 적합성을 분석한 결과, 문항 내외적합도가 기 준 범위인 .5 1.5 수준을 모두 만족하였고, 문항반응이 론의 기본가정인 일차원성도 충족하여 Rasch 모형을 적 용하는데 무리가 없는 자료인 것으로 판단된다. 이 같은 결과는 일반 고등학생을 대상으로 Rosenberg 자아존중 
감 척도가 일관된 단일요인의 척도로 구성되어 있다는 Lee 등(2009)의 연구결과를 뒷받침한다.

엘리트 청소년 축구선수에게 5점 리커트 척도로 구성 된 자아존중감 검사도구가 적절하게 기능하는지를 살펴 본 결과, Linacre(2002)가 제시한 유도지표 중 5가지 기 준을 모두 충족하는 것으로 나타났다. 본 연구의 결과는 스포츠 영재의 자아존중감을 측정하는데 있어 4점 척도 가 적합하다는 Kim et al.(2011)의 연구결과와 차이를 보이며, 이러한 결과는 연구대상의 문화적, 상황적, 연령 별 특성에 따라 최적 반응범주의 수가 달라진다는 본 연 구의 서론의 주장을 뒷받침한다.

로지트 단위로 이루어진 단일선형척도 위에서 피험자 의 능력과 문항난이도를 문항-피험자 지도를 통해 비교 하였다. RSES에서 엘리트 청소년 축구선수들이 가장 동 의하기 어렵다고 선택한 문항은 10 번 문항이었고, 가장 동의하기 쉬운 문항은 3 번 문항이었다. 이러한 결과는 스 포츠영재 아동들을 대상으로 Rosenberg 자아존중감 척 도의 문항적합도를 분석한 결과와 부분적으로 일치한다. 스포츠영재 아동들에게 매우 어려운 문항은 문항 7번과 8 번이었고, 쉬운 문항은 문항 3번과 6번이었다(Kim et al., 2011). 연구대상의 특성에 따라 어렵거나 쉽다고 느 끼는 문항에서 차이가 나타났는데, 이러한 차이는 연령대 에 따른 언어력과 어휘력의 차이 때문에 발생한 것으로 추측된다. Rasch 모형이 제공하는 장점 중 하나인 문항피험자 지도는 검사도구 개발단계에서 문항을 재구성하 는데 유용한 정보를 제공한다. 〈Figure 2〉를 살펴보면, $\mathrm{RSES}$ 에서 중간 난이도에 해당하는 문항은 고르게 분포 하고 있으나 높은 난이도에 해당하는 문항은 없는 것으로 나타났다. 스포츠영재 아동들의 연구에서는 이해하기 어 려운 문항들 즉, 난이도가 높은 문항들이 존재하는 것으 로 나타났지만 독해능력이 성인 수준에 가깝게 도달한 고 등학생 축구선수들에게는 쉽게 느껴지는 것으로 나타났 다. 이는 자아존중감 수준이 높은 피험자의 능력을 효과 적으로 변별할 수 있는 문항이 존재하지 않다는 것을 의 미하며, 따라서 향후 연구에서는 높은 수준의 자아존중감 을 보이는 피험자를 측정할 수 있는 높은 난이도의 새로 운 문항을 추가하는 것이 필요하다. 즉, 이러한 문제를 고 려할 때 훈련, 동료 및 코치와의 대인관계, 시합 상황 등 엘리트 청소년 축구선수들에게서 발생할 수 있는 구체적
인 상황을 적용한 높은 수준의 문항을 추가하는 문항 재 구성 작업이 필요하며 이를 통해 설문지의 분리 및 판별 기능을 향상시킬 수 있을 것으로 사료된다(예, "현재 우리 팀의 성적이 좋지 않지만 나는 내 자신에 대해 긍정적인 태도를 유지한다." 혹은 “팀 동료들과 비교할 때, 나는 가 끔 내 자신이 쓸모없는 사람이라고 느낀다.”).

한편, Rasch 모형의 적용은 스포츠 현장에서 선수들 의 심리상태에 관한 정보를 제공하는데 유용하게 활용될 수 있다. 예를 들어, 〈Figure 3〉은 연구대상에 포함된 엘 리트 청소년 축구선수 중 한 명의 대상자(고등학교 3학 년, 주전선수)를 선정하여 RSES로 얻어진 원점수와 로 지트 점수 간의 관계를 곡선 그래프로 나타내 원점수(35) 를 로지트 점수 $(0.74)$ 로 변환시키고, 수직선을 그어 각 문항에서 개인이 선택한 범주값(예, (2))과 Rasch 모형 결과로 나온 기댓값(예, 3)을 비교하고, 개인의 점수를 평균 능력치(logit)와 비교하여 개인과 집단 차원에서 자 아존중감 상태를 진단한 결과이다. 결과를 해석하면, 첫 째, 본 연구대상에서 무작위로 추출한 고등학교 3학년 주 전 남자 축구선수의 자아존중감은 평균(1.79)보다 낮은 수준이다. 둘째, 5 개 문항(1번, 2 번, 3 번, 8 번, 10번)에 서 관찰값과 기댓값이 동일하였다. 셋째, 4 번과 5 번 문항 은 기댓값보다 관찰값이 더 높았다. 넷째, 6 번, 7번, 9 번 문항은 관찰값이 기댓값보다 낮은 것으로 나타났다. 특히 3 개 문항 중 9번 문항 (“때때로 내 자신이 쓸모없는 사람 이라고 느껴진다")의 관찰값((2))과 기댓값(4)의 차이가 가장 큰 것으로 보아 해당 선수는 팀에서 주전임에도 자 신감이 부족하고 자신의 역할을 제대로 수행하고 있지 못 하는 상태로 파악된다. 따라서 해당 선수의 자신감을 높 이고 긍정적인 가치관 형성에 도움을 줄 수 있는 심리기 술훈련의 개입이 필요하다.

이상의 고찰을 통해 볼 때, 본 연구는 다음과 같은 장점 을 제공해준다. 첫째, 일반인의 자아존중감을 측정하기 위해 개발되어 지금까지 널리 활용되고 있는 RSES를 엘 리트 청소년 축구선수라는 특정한 대상에게 적용하여도 측정학적 측면에서 문제가 발생하지 않는다는 사실을 입 증하였다. 둘째, 로지트 점수를 활용한 측정진단표를 통 해 개인과 집단 간의 자아존중감 차이를 비교하여 실제 스포츠 현장에 적용할 수 있는 구체적인 진단 방법을 제 공하였다. 끝으로 본 연구는 다음과 같은 장점에도 불구 
하고 몇 가지 제한점을 지니고 있다. 첫째, 문항-피험자 지도를 통해 자아존중감 수준이 높은 피험자의 능력을 효 과적으로 변별할 수 있는 문항이 존재하지 않는다는 사실 이 드러났음에도 불구하고 문제의 정확한 원인을 밝히지 못하였다. 따라서 앞으로의 후속 연구에서는 난이도가 높 은 문항을 새롭게 추가하여 Rasch 모형을 다시 적용할 필요가 있겠다. 둘째, 운동선수를 대상으로 Rasch 모형 을 적용하여 RSES의 신뢰도와 타당도를 분석한 선행연 구가 거의 없었기 때문에 본 연구결과와의 비교가 쉽지 않 았다.

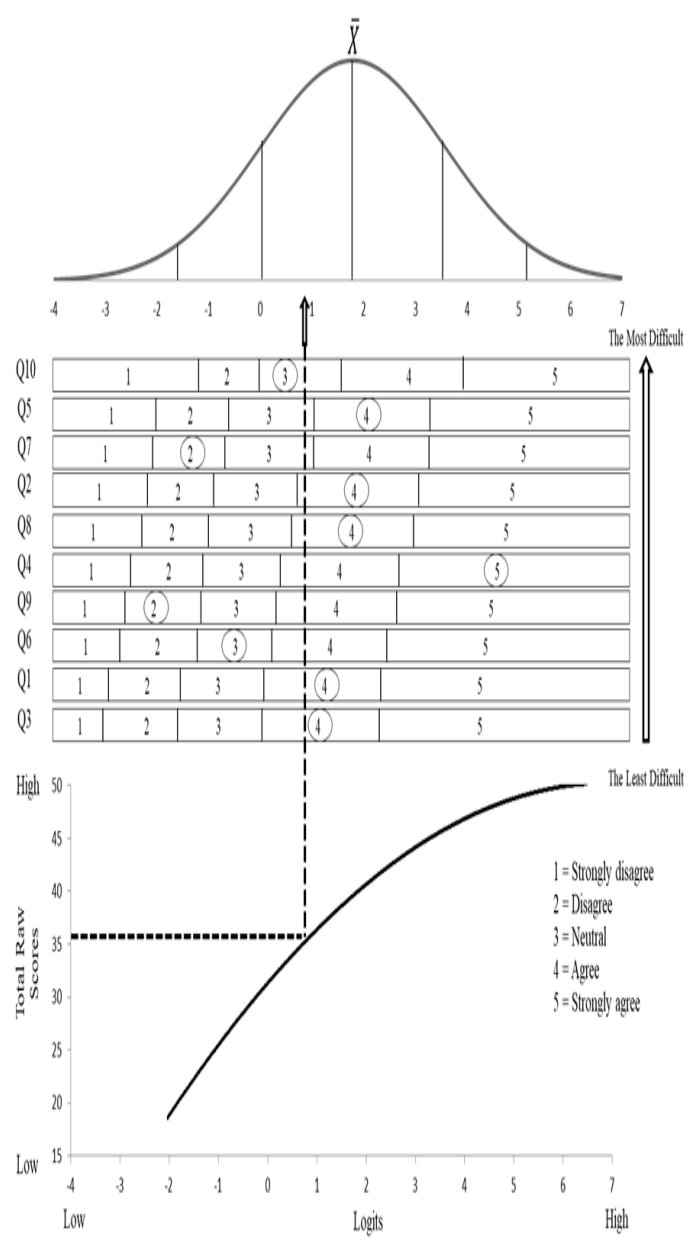

Fig. 3. A proposed diagnostic scoring and reporting sheet (Zhu et al., 2001).

\section{결론 및 제언}

본 연구는 엘리트 청소년 축구선수들을 대상으로 자아 존중감 척도의 문항적합도와 반응범주의 적절성을 2 국면 Rasch 평정척도 모형을 적용하여 척도의 심리측정학적 특성을 확인하는데 목적이 있다. 분석결과 문항의 내외적 합도가 만족할 만한 수준으로 나타나 엘리트 청소년 축구 선수들에게 적용하여도 문제가 없었다. 반응범주 수에 대 한 타당도는 5점 척도가 타당한 것으로 판단되었고, 문항 및 피험자의 분리지수와 분리신뢰도 역시 양호한 수준으 로 나타났다. 주전과 비주전 간 자아존중감 수준이 통계적 으로 유의한 차이가 있는 것으로 나타나 차이가 예상되는 집단 간 비교타당도가 검증되었다. 하지만 자아존중감 수 준이 높은 피험자의 능력을 효과적으로 변별할 수 있는 높 은 난이도의 문항이 부족한 것으로 나타나 척도의 수정이 요구된다. 또한, 후속 연구에서 선수들의 포지션과 개인의 심리적 특성을 구분하여 Rasch 모형을 적용하면 선수선 발 및 기용에 좋은 기초자료로 활용될 것으로 기대된다.

\section{참고문헌}

Anshel, M. H., Weatherby, N. L., Kang, M., \& Watson, T. (2009). Rasch calibration of a unidimensional perfectionism inventory for sport. Psychology of Sport and Exercise, 10(1), 210-216.

Bond, T. G., \& Fox, C. M. (2007). Applying the Rasch model: Fundamental measurement in the human sciences (2nd ed.). New Jersey: Lawrence Erlbaum Associates Inc.

Chao, R. C., Vidacovich, C., \& Green, K. E. (2017). Rasch analysis of the Rosenberg Self-Esteem Scale with African Americans. Psychological Assessment, 29(3), 329-342.

Choi, S., \& Cho, Y. (2013). Measurement Invariance of Self-Esteem between Male and Female Adolescents and Method Effects Associated with Negatively Worded Items. The Korean Journal of Psychology, 32(3), 571-589.

Chung, C., Koo, W., Kwon, S., Kim, B., Kim, Y., Kim, Y., ... \& Yoon, K. (2009). Sports Psychology. Seoul: Rainbow Books.

Classen, S., Velozo, C. A., \& Mann, W. C. (2007). The 
Rosenberg Self-Esteem Scale as a measure of self-esteem for the noninstitutionalized elderly. Clinical Gerontologist, 31(1), 77-93.

Cordier, R., Speyer, R., Schindler, A., Michou, E., Heijnen, B. J., Baijens, L., ... \& Joosten, A. V. (2018). Using Rasch analysis to evaluate the reliability and validity of the Swallowing Quality of Life questionnaire: an item response theory approach. Dysphagia, 33(4), 441-456.

Deering, C. G., \& Scahill, L. (2008). Mental health promotion with children and adolescents. Psychiatric Nursing: Contemporary Practice, 617-632.

Fisher, R. A. (1992). Statistical methods for research workers. Breakthroughs in statistics. New York: Springer.

Flouri, E. (2006). Parental interest in children's education, children's self-esteem and locus of control, and later educational attainment: twenty-six year follow-up of the 1970 British Birth Cohort. British Journal of Educational Psychology, 76(1), 41-55.

Goldberg, A. D. (1991). Counseling the high school student-athlete. The School Counselor, 38(5), 332-340.

Goldsmith, R. E. (1986). Dimensionality of the Rosenberg self-esteem scale. Journal of Social Behavior and Personality, 1(2), 253.

Jung, M. (2015). Relationship Between Perceived Self-Esteem, Team Commitment, and Team Climate of Youth Soccer Player. Master. Thesis, Seoul National University.

Jung, M., Kang, S., \& Kwon, S. (2016). Team Commitment as a Mediator Between Self-Esteem and Team Climate as Perceived by Korean Youth Soccer Players. Perceptual and Motor Skills, 122(3), 988-1001.

Kang, M., Zhu, W., Ragan, B. G., \& Frogley, M. (2007). Exercise barrier severity and perseverance of active youth with physical disabilities. Rehabilitation Psychology, 52(2), 170.

Kang, S. (2001). Fairness of the College Entrance Performance Assessment in Physical Education and Dance Departments. The Korean Journal of Education, 40(1), 614-629.

Kang, S., Jeon, H., Kwon, S., \& Park, S. (2015). Parental attachment as a mediator between parental social support and self-esteem as perceived by Korean sports middle and high school athletes. Perceptual and Motor Skills, 120(1), 288-303.

Kim, E., Kim, J., Lee, N., \& Lee, M. (2011). Self-Esteem Item
Goodness-of-fit in Sports Talented Children. Journal of The Korean Data \& Information Science Society, 22(3), 487-494.

Kim, I., Shin, M., \& Kwon, S. (2014). The Impact of Perceived Coaches' Interpersonal Behaviors on the Relationship Between Self-esteem and Subjective Happiness in Young Soccer Player. Journal of Coaching Development, 16(1), 149-156.

Kim, S., \& Shin, J. (2017). An Analysis of a Casual Relationship among Basketball Players' Self Encouragement Discouragement, Self Management, Self Esteem and Intention of Exercises Adherence. Journal of The Korean Entertainment Industry Association, 11(1), 123-139.

Linacre J. M. (2016). A user's guide to Winsteps ${ }^{\circledR}$ Rasch-model computer programs: program manual 3.92.0. Chicago: Mesa-Press.

Linacre, J. M. (2002). Optimizing rating scale category effectiveness. Journal of Applied Measurement, 3(1), 85-106.

Lee, J., Nam, S., Lee, M., Lee, J., \& Lee, S. (2009). Rosenberg' Self-Esteem Scale: Analysis of item-level validity. The Korean Journal of Counseling and Psychotherapy, 21(1), 173-189.

Mannarini, S. (2010). Assessing the Rosenberg Self-esteem Scale dimensionality and items functioning in relation to self-efficacy and attachment styles. JTPM Test Psychom Methodol Appl Psychol, 4, 229-242.

Ohannessian, C. M., Lerner, R. M., Lerner, J. V., \& Von Eye, A. (1995). Discrepancies in adolescents' and parents' perceptions of family functioning and adolescent emotional adjustment. The Journal of Early Adolescence, 15(4), 490-516.

Park, J., Hwang, C., \& Lee, S. (2019). Influence of Communication with Parent on Happiness of Children: Focused on Mediating Effect of Self-Esteem. Health \& Welfare, 21(1), 97-120.

Petrillo, J., Cano, S. J., McLeod, L. D., \& Coon, C. D. (2015). Using classical test theory, item response theory, and Rasch measurement theory to evaluate patient-reported outcome measures: a comparison of worked examples. Value in Health, 18(1), 25-34.

Rasch, G. (1960). Studies in mathematical psychology: I. Probabilistic models for some intelligence and attainment tests. Oxford, England: Nielsen \& Lydiche. 
Rosenberg, M. (1965). Measurement of self-esteem. In M. Rosenberg (Ed.), Society and the adolescent self-image (pp. 297-307). Princeton, NJ: Princeton University Press.

Roth, M., Decker, O., Herzberg, P. Y., Brähler, E. (2008). Dimensionality and norms of the Rosenberg Self-Esteem Scale in a German general population sample. European Journal of Psychological Assessment, 24(3), 190-197.

Schmitt, D. P., \& Allik, J. (2005). Simultaneous administration of the Rosenberg Self-Esteem Scale in 53 nations: exploring the universal and culture-specific features of global self-esteem. Journal of Personality and Social Psychology, 89(4), 623-642.

Wright, B. D., \& Linacre, J. (1994). Reasonable mean-square fit values. Rasch Measurement Transactions, 8, 370.

Wright, B. D., \& Linacre, J. M. (1989). Observations are always ordinal; measurements, however, must be interval. Archives of Physical Medicine and Rehabilitation, 70(12), 857-860.

Zhu, W., \& Kang, S.-J. (1998). Cross-cultural stability of the optimal categorization of a self-efficacy scale: A Rasch analysis. Measurement in Physical Education and Exercise Science, 2(4), 225-241.

Zhu, W., Timm, G., \& Ainsworth, B. (2001). Rasch calibration and optimal categorization of an instrument measuring women's exercise perseverance and barriers. Research Quarterly for Exercise and Sport, 72(2), 104-116.

\title{
엘리트 청소년 축구선수에 대한 Rosenberg 자아존중감 척도의 문항 및 반응범주 기능검사: Rasch 모형 활용
}

\author{
정명진 ${ }^{1}$, 김헌태 ${ }^{2}$, 강민수 ${ }^{3}$ \\ ${ }^{1}$ 미시시피대학교 대학원생 \\ ${ }^{2}$ 미시시피대학교 박사 \\ ${ }^{3}$ 미시시피대학교 교수
}

〔목적〕 본 연구는 엘리트 청소년 축구선수의 심리적 안정과 경기력 향상에 도움을 주는 자아존중감의 문항 적합도와 반응척도의 범주기능을 2 국면 Rasch 평정척도 모형을 적용하여 검사하였다. 〔방법) 대한축구협회 에 등록된 고등학교 남자 축구선수 366명에 대해 설문을 진행하였다. 측정도구로는 Rosenberg의 자아존중감 척도(RSES)를 사용하였으며, 총 10문항에 대해 5점 리커트 척도로 응답하도록 하였다. WINSTEPS 프로그 램 (version 3.65)을 이용하여 자료를 분석하였다. 〔결과) 첫째, 문항의 내외적합도는 적합도 기준을 만족하 였다. 둘째, 반응범주 수에 대한 타당도를 분석한 결과 5 점 척도가 적합하였다. 셋째, 문항-피험자 지도를 통 해 엘리트 청소년 축구선수들의 자아존중감 능력에 따른 문항의 위치를 파악하였다. 넷째, 문항 및 피험자의 분리지수와 분리신뢰도는 모두 양호한 수준으로 나타났다. 마지막으로, 주전과 비주전 선수의 자아존중감 능 력이 통계적으로 유의한 차이가 있는 것으로 나타나 차이가 예상되는 집단과의 비교(known-group difference validity)를 통한 타당도가 검증되었다. 〔결론) Rasch 분석을 통해 도출된 이러한 결과는 RSES 가 엘리트 청소년 축구선수의 자아존중감을 평가하는데 적합한 기능을 한다는 사실을 입증하였다.

주요어: 범주기능, 엘리트 고등학교 축구선수, Rasch 모형, 자아존중감 